(c) 2009 Elsevier B.V. All rights reserved.

\title{
High frequency of sediment gravity flow events in the Var submarine canyon (Mediterranean Sea)
}

\author{
Alexis Khripounoff ${ }^{\mathrm{a},{ }^{*}}$, Annick Vangriesheim ${ }^{\mathrm{a}}$, Philippe Crassous $^{\mathrm{a}}$ and Joel Etoubleau ${ }^{\mathrm{b}}$ \\ a Ifremer-Centre de Brest, Département DEEP/LEP, BP70, 29280 Plouzané, France \\ ${ }^{\mathrm{b}}$ Ifremer-Centre de Brest, Département GM, BP 70, 29280 Plouzané, France \\ *: Corresponding author: Alexis Khripounoff, Tel.: +33 2982243 02; fax: +33 29822 47 57, email \\ address : Alexis.Khripounoff@ifremer.fr
}

\begin{abstract}
:
This study aimed to analyze the role river floods play in triggering gravity flows and to investigate the role of submarine canyon systems as a conduit for terrigenous material to the deep sea. Two years of measurements in the Var canyon at depths ranging from $1200 \mathrm{~m}$ to $2350 \mathrm{~m}$ indicate that six floods of the Var River triggered hyperpycnal flows, an important mechanism for transporting particulate matter to the deep-sea floor. These sediment gravity flows were characterized by a sudden increase of current velocity that lasted 8 to $22 \mathrm{~h}$ and by downward particle fluxes that reached up to $600 \mathrm{~g} \mathrm{~m}^{-2} \mathrm{~d}^{-1}$ of particles and $3.1 \mathrm{~g} \mathrm{~m}^{-2} \mathrm{~d}^{-1}$ in terms of organic carbon. These large inputs of sediment and organic carbon may have a significant impact on deep-sea ecosystems and carbon storage in the Mediterranean Sea.
\end{abstract}

Keywords: Turbidity current; Hyperpycnal flow; Var canyon; Particle flux; West Mediterranean Sea 


\section{Introduction}

Submarine canyons are geological structures which cross continental slopes, stretching from the coast to the deep sea. They can be active and dynamic conduits for material transport and supply of organic matter to the deep sea (Canals et al., 2006). The processes that trigger sediment transport and the characteristics of particle fluxes have great implications for the carbon budget of ocean. Submarine canyons can be divided into two major groups based on their connection with the river mouth: (1) the head of the canyon is located in the immediate vicinity of the river (for example, the Congo canyon or the Var canyon in this study) or (2) the canyon is separated from the river mouth by the continental shelf (such as the Amazon canyon or the canyons in the Gulf of Lions). For the first type, the river is the main trigger of the gravity flow in the canyon (Martin et al., 2006; Puig et al., 2003; Xu et al., 2004, Palanques et al, 2005). For the second type, which represents the majority of submarine canyons, the adjacent shelf facilitates the supply and transport of sediment through hydrodynamic processes primarily related to atmospheric events (cascading) (Canals et al., 2006; Palanques et al., 2005, Palanques et al., 2006a). In several canyons, violent turbidity currents have been observed, either directly through in situ measurements (damage of scientific equipment: Khripounoff et al., 2003; Paull et al., 2003) or indirectly through historical events (submarine cable breaks: Gennesseaux et al., 1980; Heezen et al., 1964). Unfortunately, observations in canyons and other similar environments are generally limited to an isolated event at a single site. Few studies have taken simultaneous measurements along the canyon to study the frequency and intensity of gravity flow transport (de Stigter et al., 2007), which can be triggered by natural processes or by anthropogenic activities (Palanques et al., 2006b).

One goal of our work in the European HERMES program (Hotspot Ecosystem Research on the Margins of European Seas) is to identify the mechanism of material transport and deposition in a submarine canyon that receives large quantities of terrigenous input from the continent through river floods. The location of this study is the Var submarine canyon in the western Mediterranean Sea. It is directly connected to the mouth of the Var River and river-induced gravity flow activities (Gennesseaux et al., 1971). Major flooding events of the river may be responsible for frequent density (hyperpycnal) flows. The aim of our study was to address several issues: the influence of the Var River floods as the trigger mechanism of material transport, the short-term variability and the extent of this transport.

\section{Regional setting}

The continental slope is narrow along the French Riviera and virtually absent off Nice. This area comprises two major submarine canyons (Var canyon and Paillon canyon) which coalesce at a depth of $1850 \mathrm{~m}$ depth (Fig. 1). The largest canyon, the Var canyon, begins directly at the mouth of the Var River and extends about $100 \mathrm{~km}$ into the Ligurian abyssal plain down to $2600 \mathrm{~m}$ depth. The complete Var deep-sea fan has been described by Piper and Savoye (1993) and Klaucke et al. (2000). Most terrigenous material enters the submarine canyon via the Var River (120 km long) that has a drainage basin of about $2800 \mathrm{~km}^{2}$ and a pronounced seasonal regime with important flash floods in autumn and spring. This river crosses soils dominated by marls and silts. Heavy rainfall triggers the transport of terrigenous material which is injected directly into the Var canyon head. 


\section{Materials and methods}

\section{Sampling locations}

Six stations were chosen along the axis of the Var canyon (Fig.1). Two stations were located at $1200 \mathrm{~m}$ depth, one in the Var canyon (VV) and one in the Paillon canyon (VP). One station (VA) was positioned at the confluent of these two canyons at $1850 \mathrm{~m}$. The VB station was chosen in the channel thalweg at $2200 \mathrm{~m}$ depth and the VC station (1920 m depth) on the levee near VB. The most seaward station VD was located at the end of the Var channel.

\section{Flow of Var River}

A time series of the daily flow of Var River waters was determined (Fig.2) from the Nice gauging station (Banque nationale de données pour l'hydrométrie et l'hydrologie, HYDRO: http://www.hydro.eaufrance.fr) located $500 \mathrm{~m}$ upstream from the river mouth. A second gauging station was also analyzed at $35 \mathrm{~km}$ upstream from Nice on the Esteron River, a tributary of the Var River. Comparison of flow at these two stations indicated the type of flood observed at Nice, whether due to localized, scattered storms or heavy regional rainfall.

\section{Description of moorings}

Seven cruises were undertaken to recover, to repackage and to redeploy each mooring every six months for two years from October 2005 to March 2008. During this period, six moorings with sediment traps and current meters were deployed on each station along the axis of the Var canyon at water depths ranging from $1200 \mathrm{~m}$ to $2300 \mathrm{~m}$. In general, each mooring deployed for this study was composed of one Technicap sediment trap attached at $20 \mathrm{~m}$ above the bottom (a.b.) and a current meter RCM 8 (Aanderra) $10 \mathrm{~m}$ above the trap (except at VP where the moorings were not equipped with a current meter).

\section{Sampling}

Current speed and direction, as well as temperature and pressure, were recorded every 30 minutes with the RCM8 Aanderaa current meter. All the current, temperature and pressure sensors were calibrated before and after the experiment at the IfremerBrest calibration laboratory.

Settling particles were collected using two different sediment traps. The first type of trap was a cone-shaped trap (PPS5, Technicap ${ }^{\circledR}$ ) with sampling aperture of $1 \mathrm{~m}^{2}$. It was covered with a honeycomb baffle with $10 \mathrm{~cm}$ deep cells, each $1 \mathrm{~cm}$ in diameter, and it was equipped with 24 collection bottles. The sampling interval was 9 days. Because this large trap was fragile, it was deployed only at stations that were not likely to directly encounter gravity flows (stations VB, VC and VD). The second model was cylindrical trap (PPS3, Technicap $\AA$ ) with a sampling aperture of $0.05 \mathrm{~m}^{2}$. Like the large trap, the top was covered with a honeycomb baffle. It also carried 24 sampling bottles that collected samples during 9 days each.

Before mooring, sampling bottles of the traps were filled with filtered seawater and sodium borate-buffered formalin to a final concentration of $3 \%$. In the laboratory, each sample from the sediment traps was examined in toto under a dissecting microscope to sort and to count all the organisms. Then, the remaining particles were rinsed with MilliQ purified water $(\mathrm{pH} \sim 7)$, freeze-dried and weighed. Total sulfur, nitrogen and carbon 
were determined in duplicate using a Leco CNS-2000 auto-analyzer. Organic carbon concentration was measured with a Leco WR12 elemental analyzer after removing carbonates with a $2 \mathrm{~N} \mathrm{HCl}$ solution (Weliky et al., 1983). Inorganic carbon content was calculated as the difference between total and organic carbon. Analysis of the chemical composition of particles was analyzed by wavelength-dispersive X-ray fluorescence spectrometry (Siemens SRS 303 sequential X-ray spectrometer). The routine major elements were measured on samples prepared as glass disks. Calibration curves were established using a set of international reference materials (El Maghraoui et al., 1998). Data were not rectified with $\mathrm{NaCl}$ dilution.

\section{Results}

During the deployment periods, six major floods of the Var River or its tributaries were recorded (Fig. 2). In December 2005, the first measured flood induced a sudden and short current speed increase at the $\mathrm{VV}$ site with two peaks reaching up to $0.21 \mathrm{~m} \mathrm{~s}^{-1}$, and lasted $10 \mathrm{~h}$. It was associated with current direction turning from north to southeast $\left(145^{\circ}\right)$ and temperature increase of $0.1^{\circ} \mathrm{C}$ (Fig. 3). At the same time, a large peak in particle flux was detected at VV (more than $\left.120 \mathrm{~g} \mathrm{~m}^{-2} \mathrm{~d}^{-1}\right)$ and VA $\left(7.8 \mathrm{~g} \mathrm{~m}^{-2} \mathrm{~d}^{-1}\right)$ at $20 \mathrm{~m}$ a.b. (Fig. 2). No signs of this event were detected at deeper stations.

During the Var flood in February 2006 (Fig. 2), we detected an increase in current velocity and particle flux along the entire canyon at all stations, including the deepest station VD.

Surprisingly, the Var flood in August 2006 (Fig. 2) did not induce either change in the direction or speed of the current and in the particle flux along the canyon. This particularity may be due to a strong, localized storm (no floods were recorded in the Var tributaries) in the city of Nice, which, owing to urbanization of land surfaces, did not drain enough terrigenous material to the sea to trigger a turbidity current in the Var canyon.

During the Var floods in September and December 2006, we observed two current peaks of 0.57 and $0.26 \mathrm{~m} \mathrm{~s}^{-1}$ at VV and one of $0.27 \mathrm{~m} \mathrm{~s}^{-1}$ in September at VA (during the December flood, the VA mooring was not at sea). These events were characterized by a current direction change from the north to the southeast at VV and at VA, lining up with the canyon axis. The duration was $22 \mathrm{~h}$ in September and $8 \mathrm{~h}$ in December at VV and only $3 \mathrm{~h}$ at VA. A focus of the current speed during these events (Fig 3 ) shows a complex profile at these two dates with several peaks at VV. The estimated speed of propagation, calculated from the knowledge of the exact moment of their passage at each station, was $0.44 \mathrm{~m} \mathrm{~s}^{-1}$ from Nice to $\mathrm{VV}$ and $0.59 \mathrm{~m} \mathrm{~s}^{-1}$ from $\mathrm{VV}$ to $\mathrm{VA}$ in September 2006 and $0.51 \mathrm{~m} \mathrm{~s}^{-1}$ from Nice to $\mathrm{VV}$ in December 2006. A very intense particle flux was also sampled in the sediment traps at VV $\left(600 \mathrm{~g} \mathrm{~m}^{-2} \mathrm{~d}^{-1}\right)$ and at VA $\left(106 \mathrm{~g} \mathrm{~m}^{-2} \mathrm{~d}^{-1}\right)$ in September 2006. At the same time, the flux increased at VP in the, Paillon canyon $\left(2.4 \mathrm{~g} \mathrm{~m}^{-2} \mathrm{~d}^{-1}\right)$, which is connected to a very small river that crosses the city of Nice. The concomitance of flux increases at both canyons indicates an important storm event, which injected water into the entire region. The September 2006 event was the only episode during the two years of measurement that was observed at the deep VB station with a significant increase in particle flux without a peak in current speed (Fig. 2). The repercussions of the December 2006 high rainfall were recorded at VV $\left(550 \mathrm{~g} \mathrm{~m}^{-2} \mathrm{~d}^{-1}\right)$ and in the Paillon canyon at VP $\left(9.0 \mathrm{~g} \mathrm{~m}^{-2} \mathrm{~d}^{-1}\right)$. Unfortunately, the mooring at VA was not at sea at this time.

The two major events recorded at VV and VA in March and May 2007 had no direct relationship with Var River activity (Fig. 2). A strong increase in velocity was recorded $\left(0.37 \mathrm{~m} \mathrm{~s}^{-1}\right)$ at VA in March 2007 and lasted for $11 \mathrm{~h}$. No record was obtained at VV because this mooring was lost. In May, we observed a new event that was not as 
strong as the previous one, with a single peak of current speed of $0.25 \mathrm{~m} \mathrm{~s}^{-1}$ at VV (Fig 3 ) and only of $0.12 \mathrm{~m} \mathrm{~s}^{-1}$ at VA. The calculated velocity of the current between these two stations is $0.30 \mathrm{~m} \mathrm{~s}^{-1}$. The peaks of particulate matter at VA $\left(87 \mathrm{~g} \mathrm{~m}^{-2} \mathrm{~d}^{-1}\right)$ in March 2007 at VV and VA in May 2007 (98 $\mathrm{g} \mathrm{m}^{-2} \mathrm{~d}^{-1}$ and $10.5 \mathrm{~g} \mathrm{~m}^{-2} \mathrm{~d}^{-1}$, respectively) were always associated with pulses of currents, but not with river floods.

The last event was recorded in January 2008 and it was triggered by the higher Var flood $\left(480 \mathrm{~m}^{3} \mathrm{~s}^{-1}\right)$ observed during this study. This resulted in an increase in speed, recorded at VV (one peak at $0.65 \mathrm{~m} \mathrm{~s}^{-1}$ ), but the particle flux peak reached only $212 \mathrm{~g}$ $\mathrm{m}^{-2} \mathrm{~d}^{-1}$ (Fig. 3).

Finally, the characteristics common to all the observed turbidity events can be summarized by a change in current direction, which always turned to line up with the canyon axis and was associated with one or more peaks of current speed (Fig. 3). The duration of the events varied from 8 to $22 \mathrm{~h}$ while temperature increased by 0.1 to $0.2^{\circ} \mathrm{C}$ during the gravity flow.

The particle composition sampled in the Var Canyon during the quiet periods (out of events) differed little between stations (Fig. 4) and was dominated by the lithogenic fraction (alumino-silicate and carbonate). Another special feature of particle composition was its low organic carbon concentration that varied from 1.4 to $2.3 \%$ and decreased to $0.8 \%$ during the particle pulses. Only a few biological specimens were observed, mainly fragments of diatoms and foraminifers.

\section{Discussion and conclusions}

Rainstorms and episodes of intense rainfall, heavy and rapid snowmelt and torrents are typical of Mediterranean meteorological conditions and constitute the main trigger of landslides in the area. The direct link between Var River floods and the presence of current peaks and particle fluxes in the deep canyon confirms the occurrence of hyperpycnal currents in the Var River-canyon system that was described and modeled by Mulder et al. (1997a). The occurrence of these gravity flows explains the sediment transport from the river mouth to the sea bottom (Mulder and Alexander, 2001). The very interesting and original feature of the Var canyon system is the high frequency of observed avalanches (six in two years). As a result, the range of settling particle fluxes measured in this study with sediment traps is very wide, both in time and in space. Total mass fluxes spanned a broad range of values, covering three orders of magnitude at the shallowest station (1200 m depth) from 0.94 to $600 \mathrm{~g} \mathrm{~m}^{-2} \mathrm{~d}^{-1}$. Comparable observations have been made in the canyons in the northwestern Mediterranean (Puig and Palanques, 1998; Heussner et al., 2006; Martin et al., 2006).

Sediment mass transport by gravity flows affects large portion of the canyon seafloor. However, the sediment trap results also indicated that the turbidity current regularly loses material along the canyon. From September 2005 to January 2008, the Var River discharged approximately $1.07 \mathrm{Mt}$ of sediment to the sea during the six major floods. The sedimentation flux at the Var River mouth was calculated to be $1600 \mathrm{~g} \mathrm{~m}^{-2} \mathrm{~d}^{-1}$. Downward particle fluxes at $1200 \mathrm{~m}$ depth (VV) ranged from 0.94 to $600 \mathrm{~g} \mathrm{~m}^{-2} \mathrm{~d}^{-1}$ and from 2.1 to $106 \mathrm{~g} \mathrm{~m}^{-2} \mathrm{~d}^{-1}$ at $1850 \mathrm{~m}$ (VA). This rapid decrease in sedimentation flux can be explained by the settling of large particles in the upper part of the canyon. This is consistent with the model of sedimentation flux along the Var canyon (Mulder et al., 1997b). Only a small percentage of sediment was dispersed when the slope of the canyon lessens and where it widens appreciably (Fig. 1). The gravity flow reached the seaward station VB (2200 m depth) only once: the September 2006 event was the only moment when particle flow was sufficiently concentrated and energetic (Fig. 2). 
The February 2006 event featured an increase of current velocity and particle flux along the entire canyon all the way to the deepest station VD (Fig.2). We did not observe any evidence that an event propagated from the landward side to the seaward side along the canyon. The current peaks lasted more than two months, ruling out the possibility of a short triggering event, such as a flood in the Var River. The season (winter) and the simultaneity of these observations at all locations indicates that this event may have been triggered by the Liguro-Provençal current ("northern current") that flows to the southwest and that dominates the hydrological regime of this area with increases in intensity in the winter (Taupier-Letage and Millot, 1986; Millot, 1987; Sammari et al., 1995), especially in the deepest stations VB, VC and VD. During this period, the main direction of the current peaks was indeed essentially flowing from northeast to southwest, perpendicular to the canyon axis, which is the main direction of the Liguro-Provençal current. The increase in particle flux during these two months could be mainly due to sediment resuspension resulting from the increase in intensity of this current and not from a Var flood.

During the events, particle fluxes sampled in the canyon were not enriched by the same elements (Fig. 4) in the shallowest (VV and VA) and deepest stations (VB, VC and VD). Element composition depends on the origin of the sediment carried in the gravity flow. Flash floods in the Var River are generated by violent storms during spring or autumn and erode the calcareous Mercantour mountain range (French Alps) (Anthony and Julian, 1999), giving fine, dense suspended particles (Mulder et al., 2003). Floods typically transport material enriched in limestone, such as the particles carried by the submarine avalanches at the shallowest stations. In contrast, the peaks of particle flux at the seaward stations were distinguished by material enriched with silicate and aluminum due to the increase in resuspension of local, near-bottom sediment that was triggered by the intensification of the Liguro-Provencal current. The end result is the dilution of organic carbon in the particulate matter either by terrigenous (shallow stations) and/or resuspended (deep stations) material inside the canyon (Martin et al., 2006).

Beyond sediment transport, gravity flows control the carbon input along the canyon and, consequently, the impact on the deep-sea ecosystems. During the heaviest floods, we calculated that $15 \mathrm{~g} \mathrm{~m}^{-2} \mathrm{~d}^{-1}$ of particulate organic carbon (POC) was produced by the Var River discharge at its mouth. The POC flux was 1 to $3 \mathrm{~g} \mathrm{~m}^{-2} \mathrm{~d}^{-1}$ at $1200 \mathrm{~m}$ depth and 0.1 to $0.9 \mathrm{~g} \mathrm{~m}^{-2} \mathrm{~d}^{-1}$ at $1850 \mathrm{~m}$ depth. Although these flux values are lower than those obtained by the dense cascading transport system in the Gulf of Lions (Canals et al., 2006), the high frequencies of the hyperpycnal currents in the Var canyon plays an important role driving the downslope movement of carbon to the deep sea.

The in situ observations of sediment gravity flow described in this study are particular because they reveal the existence of very rapid, intense and numerous avalanches in the deep canyon triggered by the floods of a river. Our investigation confirms that the rapid formation of hyperpycnal currents (Warrick et al., 2008) can also occur in small river systems (Wheatcroft, 2000), and can be an important element of sediment mass balance in the ocean.. Collectively, small rivers in southern Europe discharge more than $140 \mathrm{Mt}$ of sediment (Milliman and Syvitski, 1992), the Var River not included in this budget. If our results are representative of submarine canyons which are directly connected to a small river, then the sum of these inputs to the deep oceans would need to be revised significantly upward in global-scale biogeochemical fluxes.

Several questions remain. How will gravity flow influence the deep-sea sedimentation in the future? To what extent are hyperpycnal currents related to climate change (storm and flooding events, as well as changes in humidity)? Will the occurrence of these currents increase with variation in precipitation intensities? The collateral consequence will be an increase in anthropogenic impacts due to urban waste, such as debris and 
garbage, that will be observed in even greater quantities in the deep canyon (Fig. 5). Finally, any changes in sediment transport patterns could affect the biodiversity in the deep-sea ecosystem, where survival rates are directly linked to continental inputs.

\section{Acknowledgements}

This paper is dedicated to Bruno Savoye who died unexpectedly in 2008 . He held vast knowledge on the Var submarine canyon and he was our mainstay, providing support and encouragement, during the Envar-Hermes program.

This research was supported by the HERMES project, EC contract $n^{\circ}$ GOCE-CT-2005511234, funded by the European Commission Sixth Framework Programme: thematic priority "Sustainable Development, Global Change and Ecosystems". This publication reflects only the views of the authors and the EC is not liable for any use that may be made of the information contained therein. We thank the captains and crews of the R/V Europe, R/V Suroit, R/V Tethys II and R/V Pourquoi Pas?. The scientific and technical staff participating in the Ifremer-Envar program is warmly acknowledged.

\section{References}

Albérola, C., Millot, C. and Font, J., 1995. On the seasonal and mesoscale variabilities of the Northern Current during the PRIMO-0 experiment in the Western Mediterranean Sea. Oceanol. Acta, 18, 163-192.

Anthony, E.J. and Julian, M., 1999. Source-to-sink sediment transfers, environmental engineering and hazard mitigation in the steep Var River catchment, French Riviera, southeastern France. Geomorphology, 31, 337-354.

Canals, M., Puig, P., Durrieu de Madron, X., Heussner, S., Palanques, A., Fabres, J., (2006) Flushing submarine canyons. Nature, 444, 354-357.

de Stigter, H.C., Boer, W., de Jesus Mendes, P.A., Jesus, C.C., Thomsen, L., van den Bergh, G.D., van Weering, T.C.E., 2007. Recent sediment transport and deposition in the Nazaré Canyon, Portuguese continental margin. Mar Geol., 246, 144-164.

El Maghraoui, M., Joron, J.-L., Etoubleau, J., Cambon, P. and Treuil, M., 1998. Determination of forty four major and trace elements in GPMA magmatic rock reference materials using X-ray fluorescence spectrometry (XRF) and instrumental neutron activation analysis (INAA). Geostandards Newslett., 23, 59-68.

Gennesseaux, M., Guibout, P. and Lacombe, H., 1971. Enregistrement de courants de turbidité dans la vallée sous-marine du Var (Alpes-Maritimes). C. R. Acad. Sci. Paris, 273, 2456-2459.

Gennesseaux, M., Mauffret, A. and Pautot, G., 1980. Les glissement sous-marins de la pente continentale niçoise et la rupture de câbles en mer Ligure (Méditerranée occidentale). C. R. Acad. Sci. Paris, 290, 959-963.

Heezen, B.C., Menzies, R.J., Schneider, E.D., Ewing, W.M. and Granelli, N.C.L., 1964. Congo submarine Canyon. AAPG Bull., 48, 1126-1149.

Heussner, S., Durrieu de Madron, X., Calafat, A., Canals, M., Carbonne, J., Delsaut, N., Saragoni, G., 2006. Spatial and temporal variability of downward particle fluxes on a continental slope: Lessons from an 8-yr experiment in the Gulf of Lions (NW Mediterranean). Mar. Geol., 234, 69-92.

Khripounoff, A., Vangriesheim, A., Babonneau, N., Crassous, P., Dennielou, B., Savoye, B., 2003. Direct observation of intense turbidity current activity in the Zaire submarine valley at 4000m water depth. Mar. Geol., 194, 151-158. 
Klaucke, I., Savoye, B. and Cochonat, P., 2000. Patterns and processes of sediment dispersal on the continental slope off Nice, SE France. Mar. Geol., 162, 405-422.

Martin, J., Palanques, A. and Puig, P., 2006. Composition and variability of downward particulate matter fluxes in the Palamos submarine canyon (NW Mediterranean). J. Mar. Syst., 60, 75-97.

Milliman, J.D. and Syvitski, J.P.M., 1992. Geomorphic/tectonic control of sediment discharge to the ocean: the importance of small mountainous rivers. J. Geol, 100, 525544.

Millot, C., 1987. The structure of mesoscale phenomena in the Ligurian Sea inferred from the DYOME experiment. Annales Geophysicae 5B (1), 21-30

Mulder, T. and Alexander, J., 2001. The physical character of subaqueous sedimentary density flows and their deposits. Sedimentology, 48, 269-299.

Mulder, T., Savoye, B. and Syvitski, J.P.M., 1997a. Numerical modelling of a mid-sized gravity flow: the 1979 Nice turbidity current (dynamics, processes, sediment budget and seafloor impact. Sedimentology, 40, 475-512.

Mulder, T., Savoye, B., Syvitski, J.P.M. and Parize, O., 1997b. Des courants hyperpycnaux dans la tête du canyon du Var. Données hydrologiques et observations de terrain. Oceanol. Acta, 20, 607-626.

Mulder, T., Syvitski, J.P.M., Migeon, S., Faugères, J.-C. and Savoye, B., 2003. Marine hyperpycnal flows: initiation behavior and related deposits. A review. Mar. Petrl. Geol., 20, 861-882.

Palanques, A., M. El Khatab, P. Puig, P. Masqué, J. A. Sanchez-Cabeza, and E. Isla. 2005. Downward particle fluxes in the Guadiaro submarine canyon depositional system (north-western Alboran Sea), a river flood dominated system. Mar. Geol., 220: 23-40.

Palanques, A., Durrieu de Madron, X., Puig, P., Fabres, J., Guillen, J., Calafat, A., Canals, M., Heussner, S., Bonnin, J., 2006a. Suspended sediment fluxes and transport processes in the Gulf of Lions submarine canyons. The role of storms and dense water cascading. Mar. Geol., 234, 43-61.

Palanques, A., J. Martín, P. Puig, J. Guillén, B. Company, and F. Sardà. 2006b. Evidence of sediment gravity flows induced by trawling in the Palamós (Fonera) submarine canyon (northwestern Mediterranean). Deep-Sea Res. 1, 53, 201-214.

Paull, C.K., Ussler III, W., Greene, H.G., Keaten, R., Mitts, P., Barry, J., 2003. Caught in the act: The 20 December 2001 gravity flow event in Monterey Canyon. Geo-Mar. Lett., 22, 227-232.

Piper, D.J.W. and Savoye, B., 1993. Processes of late Quaternary turbidity current flow and deposition on the Var deep-sea fan, north-west Mediterranean Sea. Sedimentology, 40, 557-582.

Puig, P. and Palanques, A. 1998 Temporal variability and composition of settling particle fluxes on the Barcelona continental margin, Northwestern Mediterranean. J. Marine Res., 56, 639-654

Puig, P., Ogston, A.S., Mullenbach, B.L., Nittrouer, C.A. and Sternberg, R.W., 2003. Shelf-to-canyon sediment-transport processes on the Eel continental margin (northern California). Mar. Geol., 193, 129-149.

Sammari, C., Millot, C. and Prieur, L., 1995. Aspects of the seasonal and mesoscale variabilities of the Northern Current in the Western Mediterranean Sea inferred from the PROLIG-2 and PROS-6 experiments. Deep-Sea Res. 1, 42, 893-917.

Taupier-Letage, I., Millot, C., 1986. General hydrodynamical features in the Ligurian Sea inferred from the DYOME experiment. Oceanologica Acta 9 (2), 119-131.

Warrick, J.A., Xu, J.P., Noble, M.A. and Lee, H.J., 2008. Rapid formation of hyperpycnal sediment gravity currents offshore of semi-arid California river. Cont. Shelf Res., 28, 991-1009. 
Weliky, K., Suess, E., Ungere, C., Muller, P. and Fischer, K., 1983. Problems with accurate carbon measurements in marine sediments and water column particulates: a new approach. Limnol. Oceanogr., 28, 1252-1259.

Wheatcroft, R.A., 2000. Oceanic flood sedimentation: a new perspective. Cont. Shelf Res., 20, 2059-2066.

Xu, J.P., Noble, M.A. and Rosenfeld, L.K., 2004. In-situ measurements of velocity structure within turbidity currents. Geophys. Res. Lett., 31, L09311. 
Figure caption

Fig. 1: Bathymetric map of the Var canyon showing the locations of the studied stations.

Fig. 2: Daily Var flow, total particle flux and current speed measured from September 2005 to January 2008 at each station along the Var submarine canyon.

Fig 3: Focus on the current speed (black line), temperature and current direction (grey line) during the turbidity events, $1200 \mathrm{~m}$ water depth (VV station).

Fig 4: Elemental composition of particle flux out and during the turbidity events (peak).

Fig. 5: Human impact in the deep sea: plastic rubbish at the bottom of the Var Canyon, 2200 m water depth (VB station).

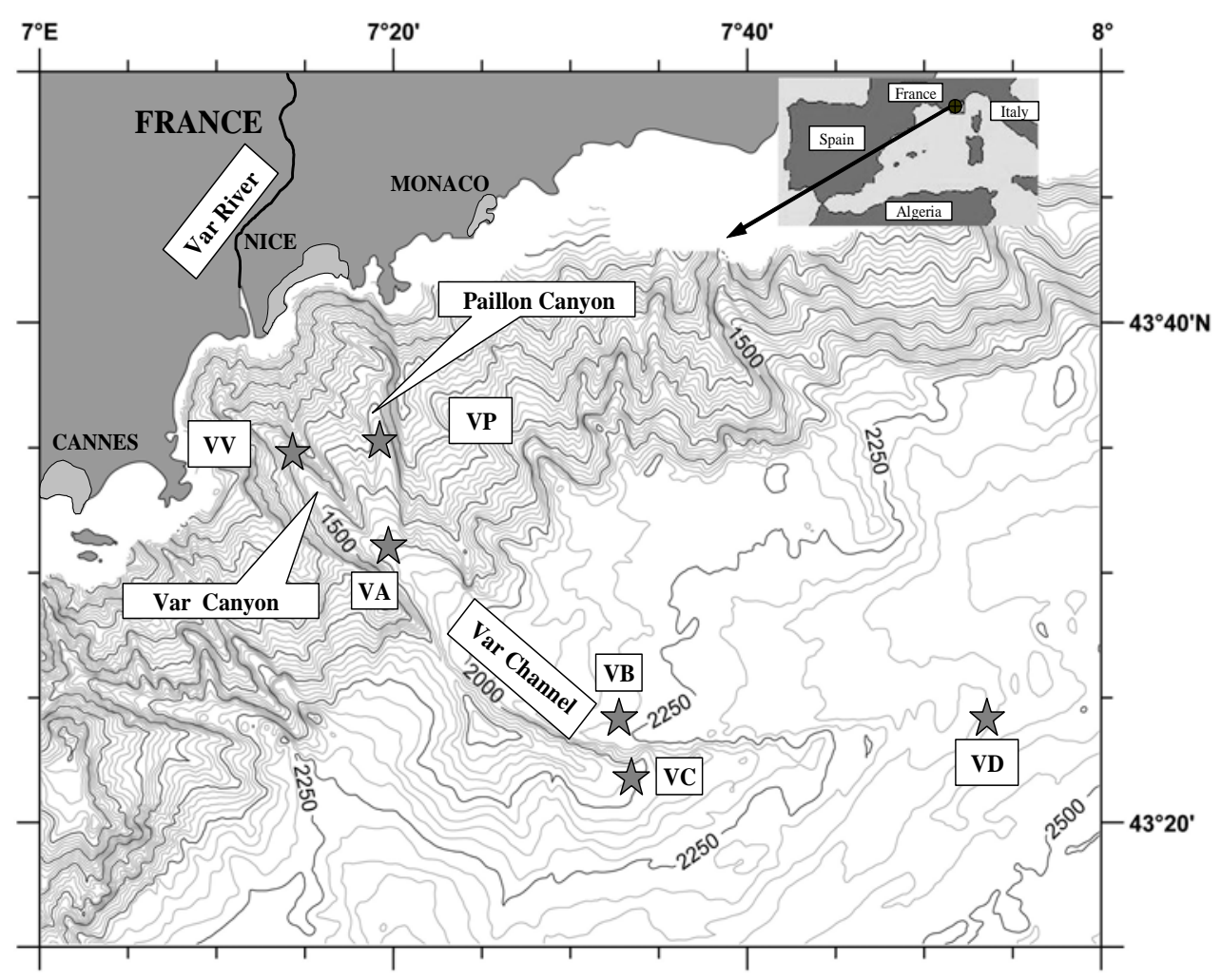



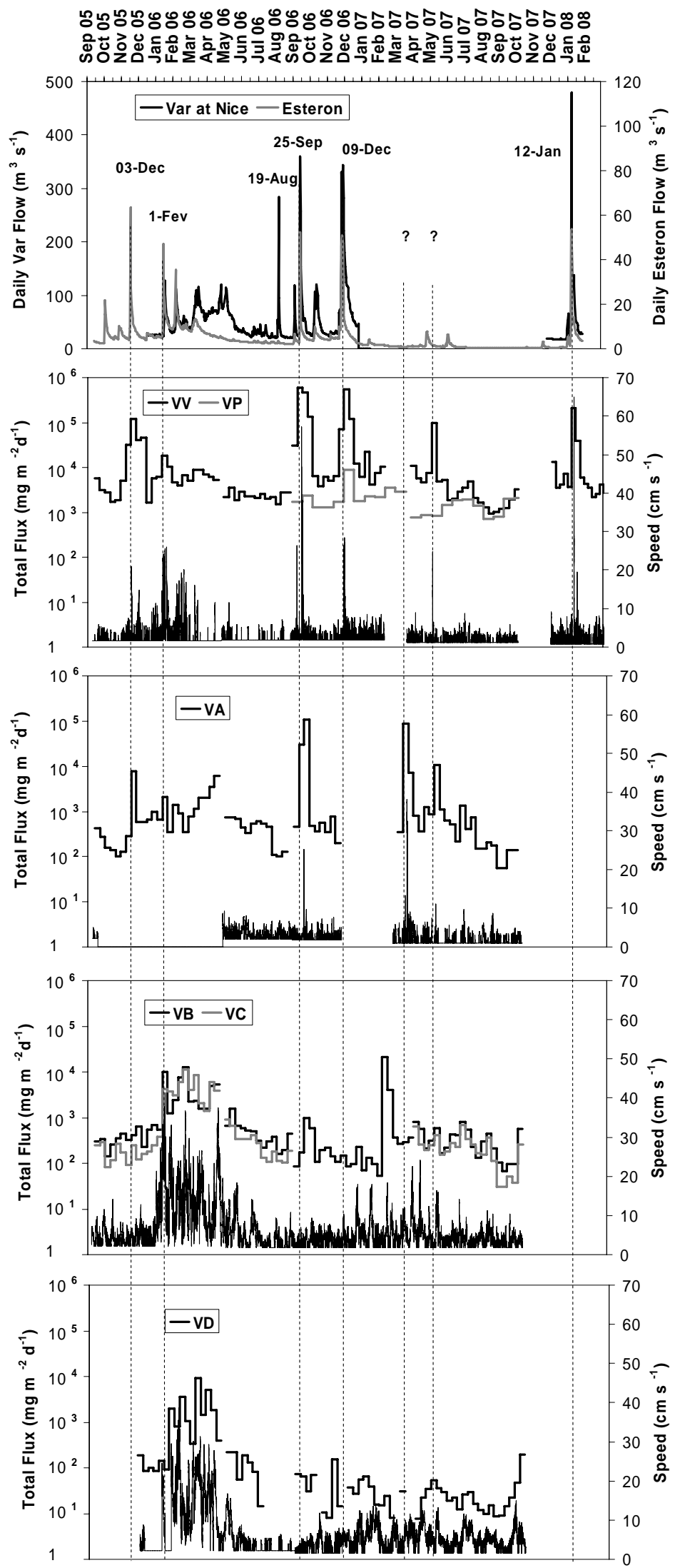

Fig2 


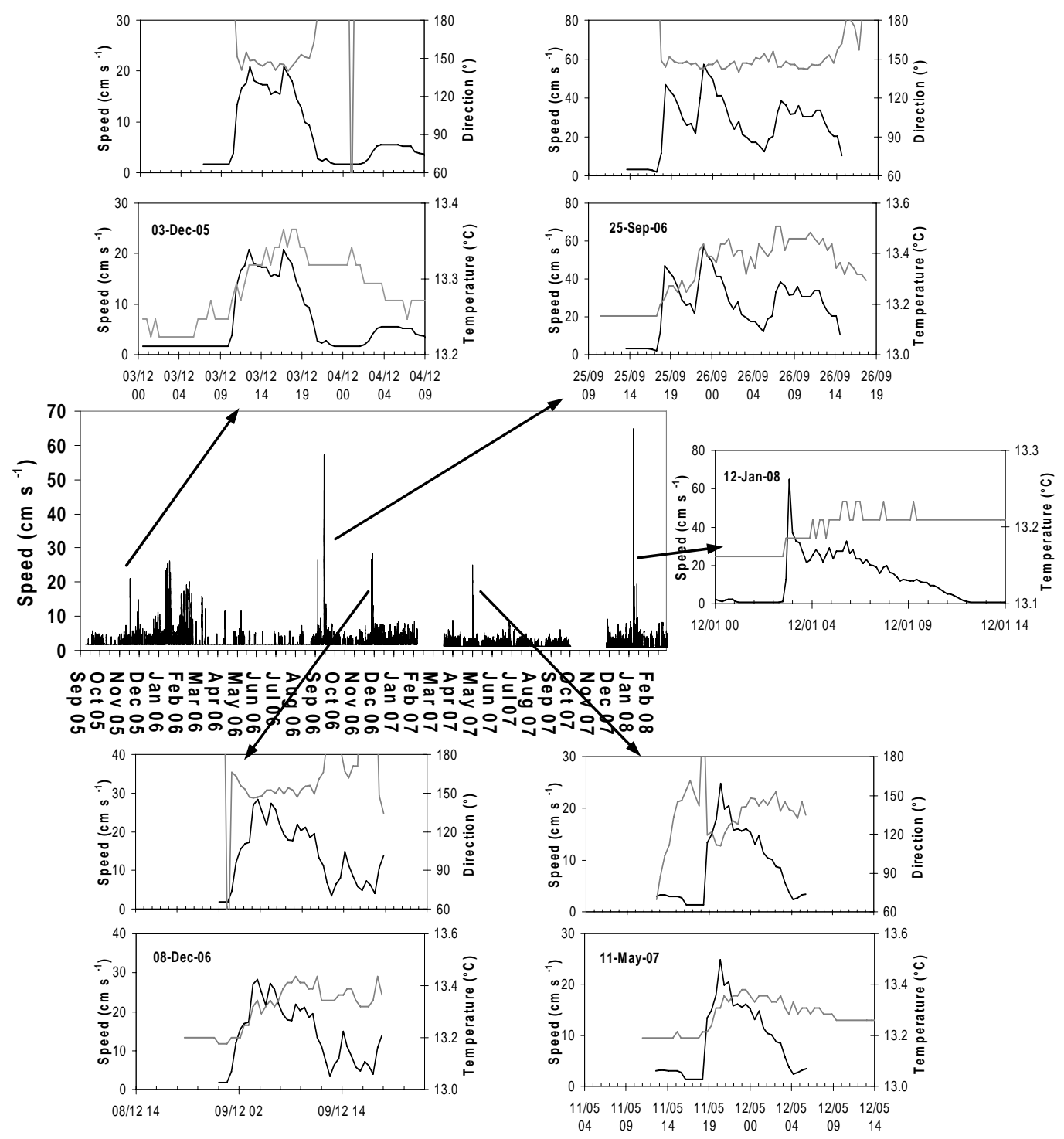

Fig 3 


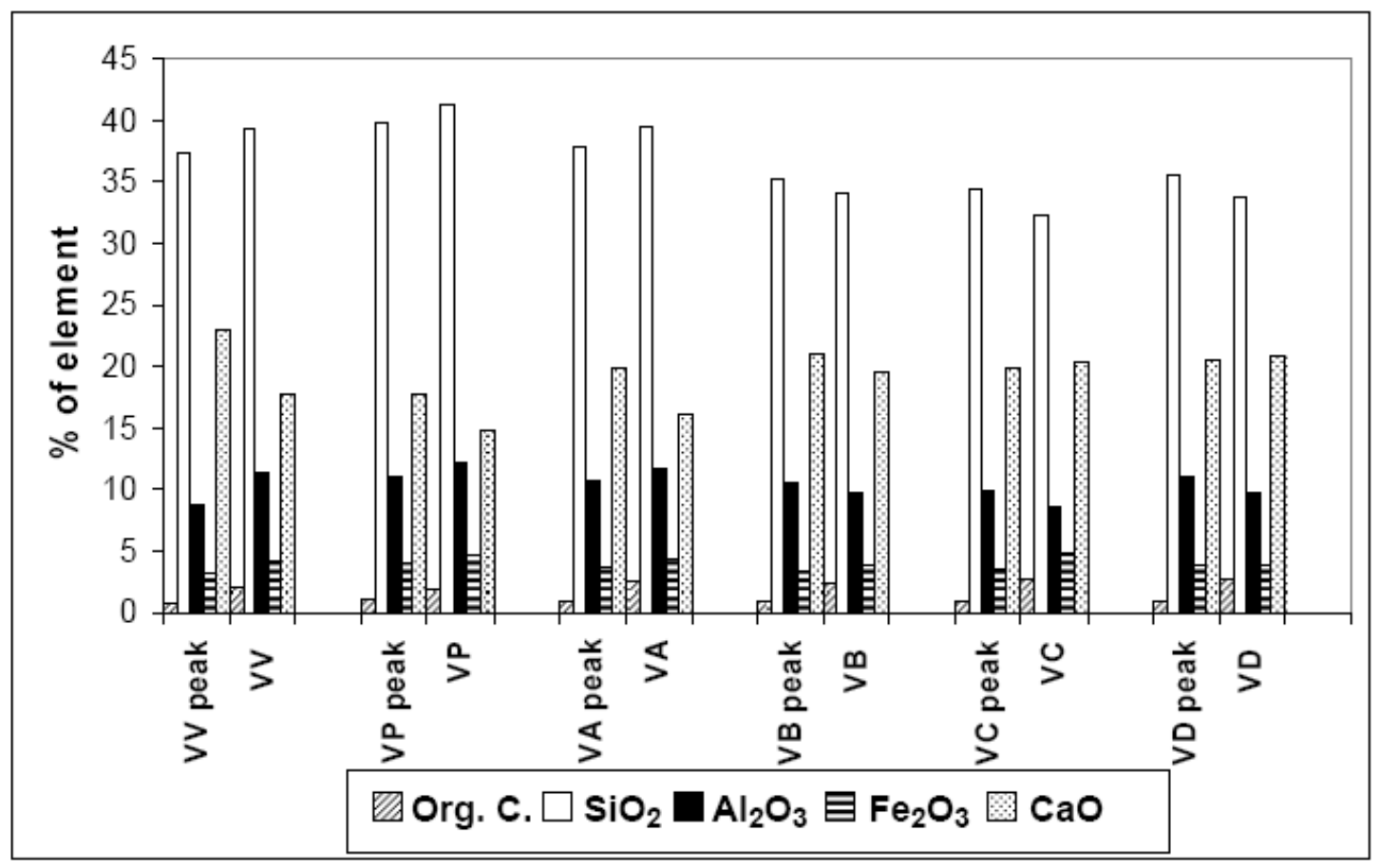

Fig4

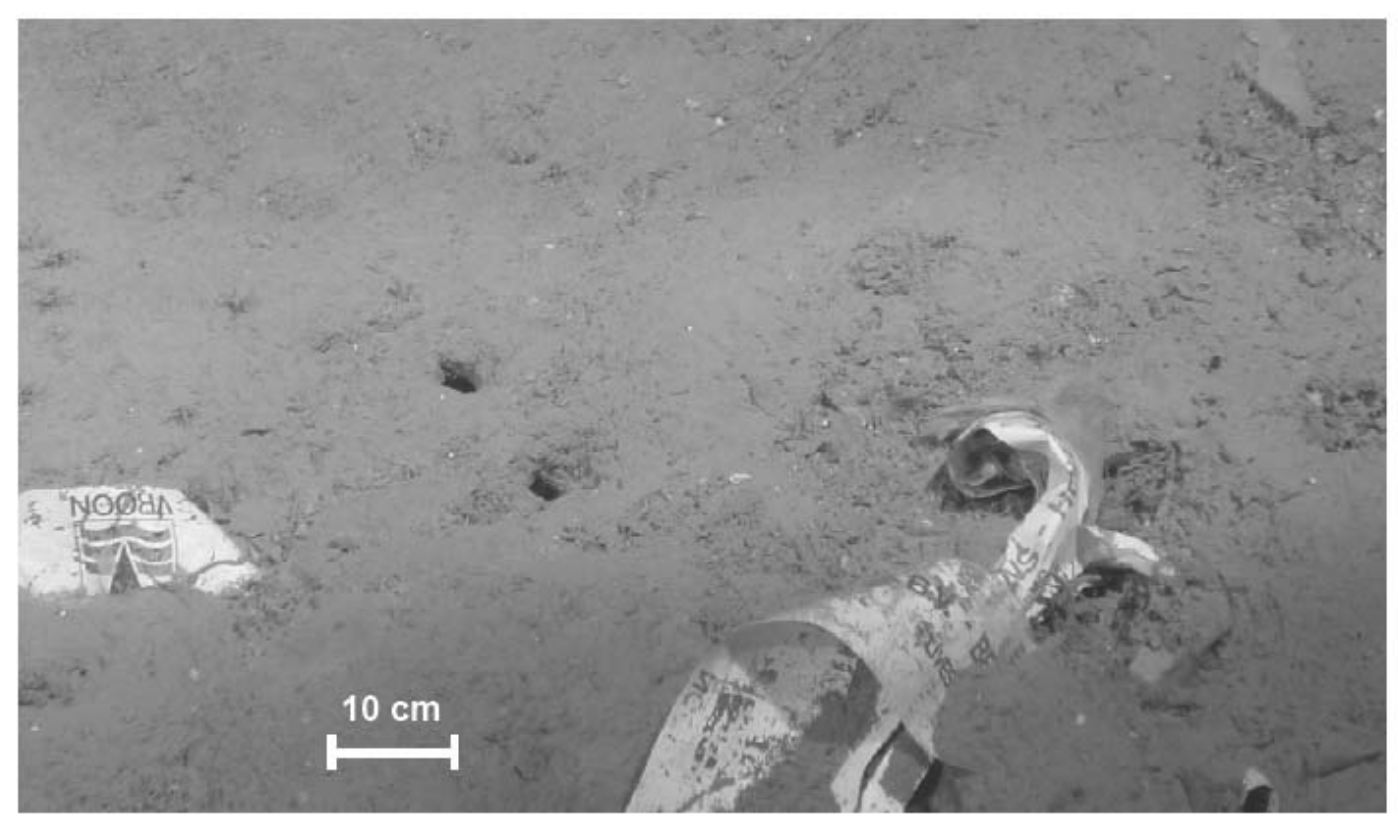

Fig 5 